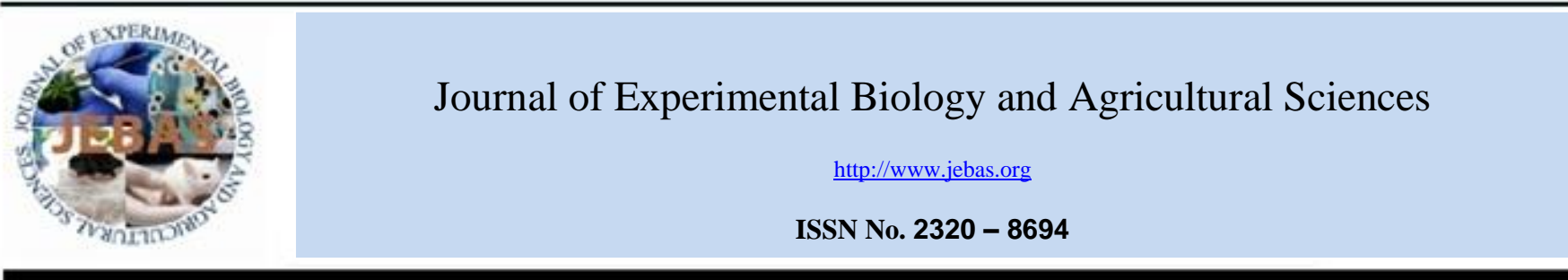

\title{
SEASONAL VARIATION IN FREE PROLINE CONTENT IN SOME SPECIES OF FAMILY EUPHORBIACEAE OF THE RAJASTHAN, INDIA
}

\author{
V. Dhaka, K. L. Meena* \\ Department of Botany, Manikya Lal Verma Government College, Bhilwara - 311001, Rajasthan, India.
}

Received - January 14, 2018; Revision - January 30, 2018; Accepted - February 19, 2018

Available Online - February 20, 2018

DOI: http://dx.doi.org/10.18006/2018.6(1).249.252

KEYWORDS
Euphorbiaceae family
Proline
Drought stress tolerance
Sikar
Rajasthan

* Corresponding author

E-mail: email: kanhaiyameena211@yahoo.com (K. L. Meena)

Peer review under responsibility of Journal of Experimental Biology and Agricultural Sciences.

Production and Hosting by Horizon Publisher India [HPI] (http://www.horizonpublisherindia.in/).

All rights reserved.

\begin{abstract}
Proline is with stress tolerance in various plants species. In the present study, free proline was estimated in the root, stem and leaves of seven species of family Euphorbiaceae collected in Rainy and Summer seasons during 2015-2016 from Sikar district of Rajasthan. Result of study revealed that proline content was higher in summer seasons as compared to other season. The maximum content of proline was reported in the stem of Euphorbia hirta while minimum was in the root of Phyllanthus maderaspatensis.
\end{abstract}

All the article published by Journal of Experimental Biology and Agricultural Sciences is licensed under a Creative Commons Attribution-NonCommercial 4.0 International License Based on a work at www.jebas.org.

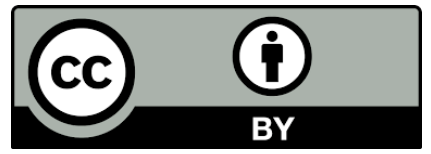




\section{Introduction}

Proline accumulation is a common metabolic response of higher plants to water deficits, and salinity stress, and has been the subject of numerous reviews over the last 20 years (Stewart \& Larher, 1980; Stewart,1981; Hanson \& Hitz, 1982; Taylor,1996; Rhodes et al.,1999).

Proline primarily accumulated in the cytosol under water stress conditions (Leigh et al., 1981; Pahlich et al., 1983). Similarly, Singh et al. (1972) reported that amount of proline found higher in drought resistance verities as compared to susceptible verities of barley. Mohammed \& Sen (1987) have examined 65 Indian desert plant species for proline contents under stressed and non- stressed condition and have reported contradictory findings that some of the well adapted desert plants do not accumulate proline. Rathore \& Sharma (1988) investigated proline contents during stress and non-stress conditions in 11 species of ferns of Rajasthan. These authors confirmed that drought resistant ferns possess more amount of proline than the aquatic or moisture loving plants. They further concluded that proline influences stress tolerance in ferns probably trough its effect on the degradation of chlorophylls and accumulation of carotenoids. Meena (2013) investigated free proline content in 12 species of family Acanthaceae in Southern Rajasthan India.

Euphorbiaceae, the spurge family, is one of the most complexes, large and diverse family of Angiosperms (Wurdack et al., 2004) with 334 genera (Webster, 1994) and over 8,000 species (Radcliffe-Smith, 2001), which are distributed mainly in the tropics in the several types of vegetations and habitats. In India, 73 genera and 410 species have been reported by Divya et al. (2011). The present study, enumerates 7 species of family Euphorbiaceae which were collected from Sikar district of Rajasthan, India and investigated for their proline content. The studied plants include Croton bonplandianum Bail, Euphorbia heterophylla L., Euphorbia hirta L., Euphorbia thymifoliaL., Phyllanthus fraternus Webster, Phyllanthus maderaspatensis L.andPhyllanthus virgatus Forst.

\section{Materials and Methods}

\subsection{Sampling area}

The sampling area is situated on the north eastern part of Rajasthan it lies between $27^{\circ} 21^{\prime}$ to $28^{\circ} 12^{\prime} \mathrm{N}$ latitudes and $74^{\circ} 44^{\prime}$ to $75^{\circ} 25^{\prime} \mathrm{E}$ longitudes. The major part of the region is an undulating sandy tract. The soil of the region varies from sandy to loam.

\subsection{Sample collection and processing}

Root, stem and leaves of all seven plant species viz., $C$. bonplandianum, E. heterophylla, E. hirta, E. thymifolia, $P$. fraternus, $P$. maderaspatensis and $P$. virgatus were collected during rainy and summer seasons of 2015 and 2016. The collected samples were brought to laboratory in plastic bags, shaded-dried and ground to make powder. Free proline was estimated in different plant parts according to Bates et al. (1973). In the process, $200 \mathrm{mg}$ of plant material was homogenized in Sulphosalicylic acid, after centrifugation, supernatant was used for free proline estimation. Optical density was recorded 2206 double beam UV-VIS Spectrophotometer at $540 \mathrm{~nm}$ wavelength. Standard curve was prepared using pure proline.

\section{Results}

Proline was estimated in rainy and summer seasons, the root, stem and leaves of C. bonplandianum, E. heterophylla, E. hirta, E. thymifolia, $P$. fraternus, $P$. maderaspatensis and $P$. virgatus of family Euphorbiaceae. The results of proline concentration have been presented in Table 1 and 2. Organ wise, among the tested various root tissues, E. heterophylla $(9.83 \mathrm{mg} / \mathrm{gdw})$ possesses highest quantity of proline while lowest proline concentration was reported from the root tissue of $P$. maderaspatensis $(2.33$ $\mathrm{mg} / \mathrm{gdw})$. In case of stem and leaves, maximum proline concentration was reported from the stem of E. hirta (26.02 $\mathrm{mg} / \mathrm{gdw}$ and $24.57 \mathrm{mg} / \mathrm{gdw}$ respectively) while minimum from $P$. virgatus stem and $P$. maderaspatensis leaves $(4.65 \mathrm{mg} / \mathrm{gdw}$ and $5.64 \mathrm{mg} / \mathrm{gdw}$ respectively).

It has been observed that the average proline content was higher in E. hirta $(18.35 \mathrm{mg} / \mathrm{gdw})$, E. thymifolia $(13.82 \mathrm{mg} / \mathrm{gdw})$ and $P$. fraternus $(10.91 \mathrm{mg} / \mathrm{gdw}$ ) as compared to the other members of family Euphorbiaceae. On the basis of proline content, $C$. bonplandianum, E. hirta, E. thymifolia and P. fraternus can be consider as the most drought tolerant species while, $E$. heterophylla, $P$. maderaspatensis and $P$. virgatus may be treated as the least drought tolerant species among the selected species of Euphorbiaceae. According to table 1 and 2 the proline content was analyzed minimum in rainy season and highest in summer season.

\section{Discussion}

Accumulation of Proline in higher plants is an indication of disturbed physiological condition, triggered by biotic or abiotic stress condition. Free proline content can increase by exposure of various drought conditions such as salinity, cold, heavy metals, or certain pathogens. Determination of free proline levels is a useful assay to monitor physiological status and to assess stress tolerance of higher plants. 
Table 1 Total free proline content $(\mathrm{mg} / \mathrm{gdw})$ in different organs of the selected species of family Euphorbiaceae during rainy season

\begin{tabular}{|clcccc|}
\hline S. No. & \multicolumn{1}{c}{ Names of species } & Root & Stem & Leaves & $\begin{array}{c}\text { Total } \\
\text { Average }\end{array}$ \\
\hline 1. & Croton bonplandianum & 6.31 & 11.80 & 13.10 & 10.40 \\
\hline 2. & Euphorbia heterophylla & 9.10 & 6.45 & 13.98 & 9.84 \\
\hline 3. & Euphorbia hirta & 3.12 & 25.13 & 24.12 & 17.45 \\
\hline 4. & Euphorbia thymifolia & 8.72 & 14.18 & 17.13 & 13.34 \\
\hline 5. & Phyllanthus fraternus & 5.21 & 6.72 & 5.70 & 5.38 \\
\hline 6. & Phyllanthus maderaspatensis & 2.33 & 8.17 & 5.21 & 6.003 \\
\hline 7. & Phyllanthus virgatus & 4.15 & 4.65 & 5.54 \\
\hline
\end{tabular}

Table 2 Total free proline content $(\mathrm{mg} / \mathrm{gdw})$ in different organs of the selected species of family euphorbiaceae during summer season

\begin{tabular}{|clcccc|}
\hline S. No. & Names of species & Root & Stem & Leaves & $\begin{array}{c}\text { Total } \\
\text { Average }\end{array}$ \\
\hline 1. & Croton bonplandianum & 6.89 & 12.17 & 14.02 & 11.02 \\
\hline 2. & Euphorbia heterophylla & 9.83 & 6.86 & 14.07 & 10.25 \\
\hline 3. & Euphorbia hirta & 4.46 & 26.02 & 24.57 & 18.35 \\
\hline 4. & Euphorbia thymifolia & 8.97 & 14.69 & 17.80 & 13.82 \\
\hline 5. & Phyllanthus fraternus & 5.83 & 7.01 & 5.87 & 5.81 \\
\hline 6. & Phyllanthus maderaspatensis & 2.87 & 8.69 & 10.00 & 6.54 \\
\hline 7. & Phyllanthus virgatus & 4.63 & 5.01 & & 5.00 \\
\hline
\end{tabular}

It is well described that the under stress conditions many species accumulate proline as an adaptive response to adverse conditioned. Although, relationship between proline accumulation and stress adaptation is not clear (Hare \& Cress, 1997) but proline estimation as drought resistance parameter can provide an ecological basis to differential tolerance in Sikar district taxa of family Euphorbiaceae. Many workers have shown the relevance of proline accumulation in condition of water stress in angiosperms. These observations have been confirmed in case of pteridophytes by Kaur et al.(1986) Gena et al. (1987) and Yadav (1990), who reported that proline content is higher in ferns growing in drought conditions compared to the ferns growing in humid conditions.

\section{Acknowledgement}

Authors are thankful to Head department of Botany, Principal and Vice Principle of the MLV Government College, Bhilwara for providing the facilities.

\section{Conflict of Interest}

The author(s) declared no potential conflicts of interest with respectto the research or publication of this article.

\section{References}

Bates LS, Waldren RP, Tare ID (1973) A rapid determination of free proline for water stress studies. Plants and Soil 39 205-207.

Divya S, Naveen KK, Ramachandran S, Dhanaraju MD (2011) Wound Healing and In Vitro Antioxidant Activities of Croton bonplandianum Leaf Extract in Rats. Global Journal of Pharmacology 53 159-163.

Gena CB, Bhardwaja TN, Sen S (1987) Distrubution and ecological studies on rajasthan species of Isoetes L. Indian Fern Journal 4: 51-54. 
Hanson AD, Hitz WD (1982) Metabolic responses of mesophytes to plant water deficits. Annual Reviews of Plant Physiology 33: 163-203.

Hare P D, Cress WA (1997) Metabolic implications of stressinduced proline accumulation in plants. Plant Growth Regulation 21: 79-102.

Kaur A, Yadav BL, Bhardwaja TN (1986) A comparative investigation of amino acids and free proline of some Rajasthan ferns. Bionature 6: 42-44.

Leigh RA, Ahmad N, Wyn Jones RG (1981) Assessment of glycine-betaine and proline compartmentation by analysis of isolated beet vacuoles. Planta 153: 34-41.

Meena KL (2013) Temporal variation in free proline content in some species of family Acanthaceae in Southern Rajasthan India. South Asian Journal of Experiment Biology 3: 37-42.

Mohammed S, Sen DN (1987) Proline accumulation in arid zone plants. Journal of Arid Environment13 231- 236.

Pahlich E, Kerres R, Jager HJ (1983) Influence of water stress on the vacuole/extravacuole distribution of proline in protoplasts of. Plant Physiology 72: 590-591

Radcliffe-Smith A (2001) Genera Euphorbiacearum. Royal Botanic Gardens KewLondon Pp 464.

Rathore D, Sharma BD (1988) Ferns of Mt Abu (Rajasthan) study of proline in relation to stress. Phytomorphology 38:259-26.

Rhodes D, Verslues PE, Sharp RE (1999) Role of amino acids in abiotic stress resistance. In Singh BK (Ed.), Plant Amino Acids: Biochemistry and biotechnology, Marcel Dekker, NY Pp. 319-356.

Singh TN, Aspmnal D, Palag LG (1972) Proline accumulation and varietal adaptability to drought in barley a potential metabolic measure of drought resistance. Nature New Biology 236 188-190.

Stewart CR (1981) Proline accumulation : Biochemical aspects. In: Paleg LG, Aspinall D (Eds) Physiology and Biochemistry of Drought Resistance in Plants, Academic Press, Sydney, Pp. 243259.

Stewart GR, Larher F (1980) Arginine synthesis, proline synthesis, and related processes. In: Miflin BJ (Ed) The Biochemistry of plants, Vol 5, Academic Press, New York, Pp. 375-403.

Taylor CB (1996) Proline and water deficit: ups and downs. Plant Cell 8:1221-1224.

Webster GL (1994) Synopsis of the genera and suprageneric taxa of Euphorbiaceae. Annals of Missouri Botanical Garden81 33144.

Wurdack KJ, Hoffmann P, Samuel BA, Vander BM, Chase MW (2004) Molecular phylogenetic analysis of Phyllanthaceae Phyllanthoideae proparte Euphorbiaceae using plastid RBCL DNA sequences. American Journal of Botany 91 1882-1900.

Yadav BL (1990) Ecological studies on Rajasthan species of Ophioglossum L. Indian fern Journal 7: 44-48. 